\title{
Self-reported personality traits in forensic populations:
}

\author{
A meta-analysis \\ Marleen Spaans (corresponding author) \\ Netherlands Institute of Forensic Psychiatry and Psychology \\ Department of Research and Education \\ Herman Gorterstraat 5, 3511 EW Utrecht, the Netherlands \\ Tel.: 00-31-88-0710240 \\ marleen.spaans@dji.minjus.nl
}

Marc L. Molendijk

Leiden University, Institute of Psychology

Wassenaarseweg 52, 2333 AK Leiden, the Netherlands

and

Leiden University Medical Center, Leiden Institute for Brain and Cognition

Postbus 9600, 2300 RC Leiden, the Netherlands

Tel.: 00-31-71-5278482

m.l.molendijk@fsw.leidenuniv.nl; molendijkml@gmail.com

Edwin de Beurs

SBG Foundation for Benchmarking Mental Health Care

Rembrandtlaan 46, 3723 BK Bilthoven, the Netherlands

and

Leiden University, Institute of Psychology

Wassenaarseweg 52, 2333 AK Leiden, the Netherlands 
Tel.: 00-31-71-5278482

edwin.debeurs@sbggz.nl

Thomas Rinne

Netherlands Institute of Forensic Psychiatry and Psychology

Department of Research and Education

Herman Gorterstraat 5, 3511 EW Utrecht, the Netherlands

Tel.: 00-31-88-0710240

t.rinne@dji.minjus.nl

Philip Spinhoven

Leiden University, Institute of Psychology

Wassenaarseweg 52, 2333 AK Leiden, the Netherlands

and

Leiden University Medical Center, Department of Psychiatry

Postbus 9600, 2300 RC Leiden, the Netherlands

Tel.: 00-31-71-5278482

spinhoven@fsw.leidenuniv.nl 


\title{
Self-reported personality traits in forensic populations: A meta-analysis
}

\author{
Abstract \\ The current study covers a systematic review and meta-analysis of the prevalence of self- \\ reported deviant or disruptive personality traits: anger, aggression, hostility, antisocial \\ traits, psychopathy, and impulsivity in forensic populations worldwide. A computer- \\ based search of titles was carried out using the PubMed electronic database for articles \\ published in English that included a self-report instrument for personality characteristics \\ in combination with a forensic population (i.e., detained in remand, sentenced and/or in \\ enforced treatment, or on parole). The final sample consisted of 39 studies $(N=11,716)$ \\ that together used 17 different instruments and reported on 32 subscales or constructs that \\ fitted our current interest. Results showed significantly higher levels of self-reported \\ antisocial and psychopathic features in forensic samples, including a significant effect of \\ the assessment instrument and subscale used. No significant differences were found for \\ self-reported impulsivity, anger, aggression, or hostility in forensic populations compared \\ to norm scores of non-forensic samples. Possible explanations, including suggestions that \\ forensic populations are prone to providing socially desirable answers on self-report \\ questionnaires, possibly to gain advantages such as a lower prison sentence or to avoid \\ enforced treatment, are discussed, as well as limitations, and suggestions for future \\ research and clinical practice.
}

\section{Key words}

Meta-analysis, systematic review, forensic populations, personality traits, self-report 


\section{Introduction}

According to a systematic review carried out by Fazel and Danesh in 2002, 65\% of the male general prison population and $42 \%$ of the female general prison population in western countries has a personality disorder, based on interview methods of assessing these disorders. The authors also found that prisoners are ten times more likely to have antisocial personality disorder than the general population, with a prevalence of $47 \%$ in men and of $21 \%$ in women.

Many of the separate personality traits that correspond to antisocial personality disorder and narcissistic personality disorder have been studied individually and shown to have a relationship with deviant or disruptive behaviours - such as antisocial features (Edens, Buffington-Vollum, Colwell, Johnson, \& Johnson, 2002; Shechory, Weiss, \& Weinstain, 2013), psychopathic features (Dolan \& Blackburn, 2006; Edens et al., 2002; Hare, 2006; Neumann \& Hare, 2008), anger (Norlander \& Eckhardt, 2005; Taft, O’Farrell, Torres, Panuzio, Monson, Murphy, \& Murphy, 2006), aggression (Boccaccini, Murrie, Hawes, Simpler, \& Johnson, 2010; Dolan \& Blackburn, 2006; Shechory et al., 2013; Walters, 2007), hostility (Dolan \& Blackburn, 2006; Norlander \& Eckhardt, 2005), impulsivity (Cunradi, Todd, Duke, \& Ames, 2009), and dominance (Dolan \& Blackburn, 2006).

In order to contribute to understanding the role of personality in crime within the field of criminology, Miller and Lynam (2001) carried out a meta-analysis on the relationship between a broad interpretation of antisocial behaviours and basic dimensions of personality. Results of 59 studies indicated that the dimensions agreeableness and conscientiousness, from Costa and McCrae's Five-Factor Model (FFM; Costa \& McCrae, 1990), showed the strongest association with antisocial behaviours. Similarly, Miller, Lynam, Widiger, and Leukefeld (2001) studied the relationship between psychopathy and 
the FFM. Studies show that individuals who commit crime or are psychopaths are generally low in agreeableness, exhibiting negative interpersonal and psychopathic characteristics such as deceitfulness, manipulativeness, and a grandiose sense of selfworth, low in conscientiousness, meaning they lack responsibility and are unreliable (Miller \& Lynam, 2001; Miller \& Lynam, 2003; Miller et al., 2001) and also display high levels of facets of neuroticism, pertaining to angry hostility and impulsiveness (Miller \& Lynam, 2015; Widiger \& Costa, 2012).

In line with these above-mentioned studies, the current study examines negative, inflexible, and notable personality traits - as maladaptive or severe variants of the common dimensions of personality encompassed by the FFM - that together have the potential to cause antisocial or criminal behaviour and the accompanying likelihood of considerable damage or distress to persons and society. The importance of studying separate personality traits is stressed in earlier versions of the Diagnostic and Statistical Manual of Mental Disorders (DSM-IV-TR; American Psychiatric Association, 2000) which provided for the opportunity to record maladaptive personality traits that may be below the threshold of a disorder, but still of great diagnostic importance. Examining severe variants of common personality dimensions, even when they may not constitute a personality disorder, is also more in line with the proposed dimensional approach to personality disorder as presented in the DSM-5 (American Psychiatric Association, 2013). The aim of this study was to contribute to finding the best way to assess, describe, and diagnose severe variants of common personality traits and the ensuing antisocial or criminal behaviour - in order to add to existing knowledge on the role of personality in crime, to be able to better treat personality disordered individuals, and ideally to eventually prevent crime. 


\section{Self-report method}

In order to further study the severe variants of common personality traits that accompany antisocial behaviour in forensic populations - such as those belonging to DSM-5 Cluster B antisocial personality disorder and narcissistic personality disorder - the actual extent to which they are present should first be assessed. Ideally this is also done within forensically relevant subgroups differing in age, gender, and type of crime committed. The above-mentioned selection of studies used a wide variety of assessment methods to evaluate maladaptive or severe personality traits, ranging from self-report measures to observer-rated scales and semi-structured interviews. Of these methods, self-report assessments are the least complicated and least time-consuming. However, the validity of self-report methods in forensic populations that show the most deviant or disruptive behaviours is questionable, partly due to the fact that forensic psychiatric patients can have a lot to gain or lose from the results of their assessment, such as the length of their prison sentence or whether or not they receive enforced treatment (Milton et al., 2005; Spaans, Barendregt, Muller, De Beurs, Nijman, \& Rinne, 2009; Spaans, Rinne, De Beurs, \& Spinhoven, 2015). Moreover, given the great diversity of self-report instruments for personality traits, there appears to be little clarity or overview of the current level of knowledge on the subject. The aim of the present study is therefore to review which personality traits, assessed with self-report measures, are most prevalent in forensic settings.

The current study investigates antisocial behaviour and psychopathic features and the severe variants of common personality traits of the two most relevant personality dimensions of agreeableness, neuroticism, and conscientiousness in forensic populations, i.e. self-reported anger, aggression, hostility, and respectively, impulsivity. 


\section{Method}

A computer-based search of titles was carried out using the PubMed electronic database for articles published in English that included a self-report instrument for personality characteristics in combination with a forensic population (i.e., detained in remand, sentenced and/or in enforced treatment, or on parole). The search strategy for the current study is presented in Appendix 1. There were no geographical and/or cultural restrictions, or restrictions on time period in which the studies were conducted or research design. This search strategy resulted in 2,840 potential articles, published between 1946 and 2015. Further possibly relevant publications were obtained from reference lists.

Titles and abstracts were screened for appropriateness regarding inclusion in the current study by MS and a research assistant. Exclusion of articles was discussed between the two and in cases of disagreement MLM was consulted. Along with 29 additional articles identified through other sources, a total of 187 articles were selected for full text assessment in more detail. These articles contained a total of 180 different subscales to measure personality characteristics with. Studies were excluded if they were written in a language other than English, if the study population was juvenile or adolescent, if the study did not assess a personality trait related to anger, aggression, hostility, antisocial traits, psychopathy, and impulsivity, if the study population was not suspected of or charged with a crime, or if the (self-report) assessment instrument used in the study was not specified or validated. As anger was considered to be a personality trait within the context of the current study (Martin, Watson, \& Wan, 2000), assessment instruments were chosen that contained subscales pertaining to trait anger.

\section{Extraction of data}

Initially, 58 articles were selected for the study, based on whether they reported mean scores on (sub)scales corresponding to anger, aggression, hostility, antisocial traits, 
psychopathy, and impulsivity in forensic populations. Authors of articles that did not cite sample size, mean, and/or standard deviations of personality characteristics were contacted via e-mail and were asked to provide this data. Seven studies for which the relevant data could not be collected this way were excluded from further analyses.

A small number of studies $(n=5)$ reported mean personality scores for a forensic population as well as for healthy controls from the same study. In those cases, the norm or reference scores were extracted from the article. In the other 34 cases where there was no mention of controls generated from the general or healthy population in the same study, manuals were requested from the corresponding publishers in order to compare mean scores of forensic population to norm scores of the self-report instruments. For those that could not be provided, literature searches were carried out to find published articles containing the original norm or reference scores for the particular self-report instruments. Where no original norm or reference scores could be found, other available publications were used for reference scores. The highest available match for country of origin, versions of the self-report instruments, year of study, and socio-demographic variables of the forensic sample was chosen where possible. The most preferable sources for this information were introductions to the instrument and validation studies. Instruments for which neither a manual nor relevant publications could be found were excluded from this study, as well as one case in which the norm or reference scores that were found through the above-mentioned method were presented in very wide ranges of normalized $\mathrm{T}$ scores that could not be matched to the exact $\mathrm{T}$ scores given in the study and no further information could be found or provided. The source of the norm or reference scores was included in the meta-analysis as a potential moderator variable: derived from the original article, general norms derived from manuals, or reference scores derived from other publications. 
In order to obtain sufficient sample size per personality trait for analysis, it was decided to group the personality traits together into three central categories: (1) Antisocial/Psychopathy, (2) Anger/Aggression/Hostility, and (3) Impulsivity. This corresponds closely with the conceptualizing of severe variants of personality traits by Miller and Lynam (2001; 2003; 2015), Miller and colleagues (2001), and Widiger and Costa (2012), with the first category representing features of antisocial and psychopathic behaviour in general and the latter two categories representing the more negative features of the FFM dimensions agreeableness and conscientiousness, respectively.

Means, standard deviations, sample sizes, and data concerning potential moderators were extracted from each article by MS and a research assistant. Categorical variables included the name or kind of the assessment instrument, the name or kind of subscale or construct used, the judicial phase the study sample was in (i.e., remanded, convicted, probationed, and/or in treatment), gender distribution of the sample (only males, only females, or mixed), country of origin, source of the reference or control means, standard deviations, sample sizes, the type of crime(s) for which the study sample was incarcerated, and the numerical variables mean age in years and year of study.

The final sample consisted of 39 studies that together used 17 different instruments and 32 subscales or constructs. The search process is shown in a flow diagram in Appendix 2. Table 1 shows the three categories of personality traits along with corresponding constructs or subscales in alphabetical order, assessment instrument, and citation(s) per construct [Table 1 near here].

\section{Analysis}

Comprehensive Meta-Analysis (CMA; Borenstein, Hedges, Higgins, \& Rothstein, 2005) software was used to calculate pooled effect size estimates over studies. Moderator analyses and meta-regression analyses were carried out with the above-mentioned 
potential moderator variables. With regard to the moderator analyses, outcomes from multiple subgroups within the same study were treated as not completely independent. Methodological quality of the included studies was assessed using an adapted version of the Newcastle-Ottawa Scale for assessing the quality of non-randomized studies in metaanalyses (NOS; Wells et al., 2015). Publication bias was examined for each outcome category by means of funnel-plots.

\section{Results}

Table 2 provides the 39 included studies (total $N=11,716)$ along with instrument(s) and subscale(s) used and sample size by study. Results of the meta-analysis are presented for each overall category separately [Table 2 near here].

\section{Antisocial/Psychopathy}

Random effect models for the 27 studies $(n=8,263)$ that assessed self-reported antisocial and psychopathic features showed higher scores on these traits in forensic samples compared to reference populations with a large effect size $(g=1.05,95 \% \mathrm{CI}=0.78-$ 1.32, $p<.001)$. Results also showed between-study heterogeneity $\left(I^{2}=98.87, Q=\right.$ $5130.35, p<.001)$

The studies used the Minnesota Multiphasic Personality Inventory (MMPI) versions 1 and/or 168, the MMPI-2, the Personality Assessment Inventory (PAI), the Balanced Emotional Empathy Test (BEES), Edwards Personal Preference Schedule (EPPS), Interpersonal Reactivity Index (IRI), and Schedule for Nonadaptive and Adaptive Personality (SNAP). Moderator analyses showed a significant moderation effect of the assessment instrument $(\mathrm{Q}=94.34, \mathrm{df}=7, p<.001 ; g=0.07,95 \% \mathrm{CI}=-0.03$ $-0.16)$ and subscale used $(\mathrm{Q}=88.45, \mathrm{df}=5, p<.001 ; g=0.05,95 \% \mathrm{CI}=-0.05-0.15$; see Table 3 for effect sizes), indicating slightly different self-reported levels of antisocial and psychopathic features depending on which instrument or subscale was used. Due to 
the significant and large effects of all versions of the MMPI, and given the suggestion of restricted usefulness of the MMPI(-2) within a forensic context by Spaans and colleagues (2009), it was decided to investigate a possible difference in self-reported levels of antisocial and psychopathic features between the MMPI and other instruments. Results showed that with the division of the instruments used into MMPI vs. other instruments, the significant effect of the assessment instrument used remained $(\mathrm{Q}=12.71, \mathrm{df}=1, p<$ $.001)$, with a large effect size of $1.39(p<.001)$ for all versions of the MMPI, compared to a moderate effect size of $0.46(p<.001)$ for all other instruments. This indicated different levels of self-reported antisocial and psychopathic traits when using the MMPI compared to other instruments.

Moderator analyses of country of sample origin showed a significant moderation effect $(\mathrm{Q}=129.40, \mathrm{df}=4, p<.001 ; g=0.52,95 \% \mathrm{CI}=0.43-0.62)$. Effect sizes and significance per country of sample origin, as shown in Table 3, indicated that levels of self-reported antisocial and psychopathic traits differ between forensic populations and reference populations in Belgium, the United States, and Israel. Gender showed a large significant overall effect $(\mathrm{Q}=76.63, \mathrm{df}=3, p<.001 ; g=1.53,95 \% \mathrm{CI}=$ $1.39-1.66)$, indicating significantly different levels of self-reported antisocial and psychopathic traits between the male and mixed samples in forensic populations and reference populations. Given that the large pooled effect size for female samples $(g=$ 1.41) was based on only two studies, this is most likely due to low power (see Table 3). There were several categories for judicial phase within the samples (see Table 3). Judicial phase showed a significant moderation effect $(\mathrm{Q}=43.06, \mathrm{df}=5, p<.001 ; g=0.57,95 \%$ $\mathrm{CI}=0.51-0.63)$. Results indicated that for every judicial phase, significant differences in level of psychopathic or antisocial traits were observed between the forensic samples and the reference populations (see Table 3). 
A moderator analysis for type of crime revealed a large significant effect on levels of self-reported antisocial and psychopathic traits $(\mathrm{Q}=96.81, \mathrm{df}=6, p<.001 ; g=$ $1.55,95 \% \mathrm{CI}=1.45-1.66)$, indicating differences between forensic populations that were incarcerated for felonies, misdemeanours, sex offenses, and other serious offenses compared to non-forensic populations. Eight studies did not specify the type of crime for which their study sample was incarcerated. Results for categories of source of the control or reference scores showed a large significant moderation effect $(\mathrm{Q}=8.58, \mathrm{df}=1, p<$ $.001 ; g=0.91,95 \% \mathrm{CI}=0.67-1.15)$ indicating differences in levels of self-reported antisocial and psychopathic traits when means and standard deviations were compared to previously published general norms versus comparisons with a control group in the corresponding study (see Table 3). [Table 3 near here]

Meta-regression analysis on mean age of the forensic sample and year of study showed no significant effect of these possible moderator variables (Coeff. $=-.02, p$ $=.46$; Coeff. $=-.00, \mathrm{p}=.67$, respectively). Inspection of the funnel plot for publication bias showed an even distribution of the 27 studies across the combined effect size, indicating that a meaningful publication bias was unlikely.

\section{Anger/Aggression/Hostility}

No statistically significant overall effect was found for self-reported anger, aggression and hostility in forensic populations $(g=.19,95 \% \mathrm{CI}=-.03-.42, p=.09)$ for the 21 corresponding studies $(n=5,692)$. Between-study heterogeneity was found $\left(I^{2}=97.07, Q\right.$ $=1329.719, p<.001)$.

The studies used the Personality Assessment Inventory (PAI), the Edwards Personal Preference Schedule (EPPS), the Anger Expression (AX) Scale, the State-Trait Anger Expression Inventory (STAXI), the State-Trait Anger Scale (STAS), the Buss Durkee Hostility Inventory (BDHI), the Aggression Questionnaire (AQ), and the 
Schedule for Nonadaptive and Adaptive Personality (SNAP). A moderator analysis showed a significant effect of the assessment instrument used $(\mathrm{Q}=38.92, \mathrm{df}=7, p<$ .001 ), although the point estimate corresponding to the overall effect was 0.09 , indicating a very small effect. Table 4 shows the results per instrument used, including effects for the AX, EPPS, SNAP, and STAXI. A moderator analysis for subscale used showed no significant effect $(\mathrm{Q}=14.80, \mathrm{df}=10, p<.14$; see Table 4 for effect sizes $)$. More than half of the subscales used were named 'aggression' (52.9\%). The point estimate corresponding to the overall effect was 0.01 , showing almost no effect.

Moderator analyses of country of sample origin showed a small significant overall moderation effect $(\mathrm{Q}=53.41, \mathrm{df}=5, p<.001 ; g=-.13,95 \% \mathrm{CI}=-0.22-0.04)$. Effect sizes per country are shown in Table 4 and indicate differences in levels of selfreported anger, aggression and hostility in Spanish, Italian, and Canadian forensic populations compared to reference populations. Gender also showed a small significant moderation effect $(\mathrm{Q}=94.50, \mathrm{df}=2, p<.001 ; g=0.16,95 \% \mathrm{CI}=0.05-0.26)$. Effect sizes per gender group indicate different levels of self-reported anger, aggression, and hostility in female forensic populations and in mixed samples (see Table 4). Judicial phase showed a moderate significant effect $(\mathrm{Q}=126.66, \mathrm{df}=5, p<.001 ; g=0.44,95 \%$ $\mathrm{CI}=0.34-0.53)$. Effect sizes and significance per judicial phase indicate significant differences in levels of self-reported anger, aggression, and hostility in forensic populations on probation and in treatment at the same time, in populations in remand, and in samples with a mix of remanded and convicted offenders receiving treatment, compared to non-imprisoned populations (see Table 4).

Six studies did not provide information on the specific type of crime. Overall results of the moderator analysis showed a moderately negative significant effect $(\mathrm{Q}=$ 112.98, $\mathrm{df}=5, p<.001 ; g=-0.68,95 \% \mathrm{CI}=-0.83-0.53)$. Different levels of anger, 
aggression, and hostility were self-reported in forensic populations that were incarcerated for gender violence. Only one study featured reference scores of a non-incarcerated sample alongside forensic scores. Results of the moderator analysis showed a small significant effect $(\mathrm{Q}=16.39, \mathrm{df}=1, p<.001 ; g=0.35,95 \% \mathrm{CI}=0.16-0.54)$. Effect sizes for the two sources of the reference scores are shown in Table 4. [Table 4 near here] Meta-regression analysis on mean age of the forensic sample and year of study showed no significant effects of these possible moderator variables (Coeff. $=-.02, p$ $=38$; Coeff. $=-.01, \mathrm{p}=.10$, respectively). Inspection of the funnel plot for publication bias showed an even distribution of the 21 studies across the combined effect size, again indicating that a meaningful publication bias was unlikely.

\section{Impulsivity}

The analyses for self-reported impulsivity found no significant overall differences between forensic populations and reference groups $(g=-.16,95 \% \mathrm{CI}=-.71-.39, p=$ $.56)$, for the eight corresponding studies $(n=1,664)$. Results showed between-studies heterogeneity $\left(I^{2}=98.144, Q=484.83, p<.001\right)$.

The eight studies used the Barratt Impulsiveness Scale (BIS) version 11, the BIS version 10, the Emotionality, Activity, Sociability, and Impulsivity (EASI) scale, the Eysenck Impulsiveness Scale (EIS), and the SNAP. Moderator analyses showed significant effects for the assessment instrument used $(\mathrm{Q}=47.21, \mathrm{df}=4, p<.001)$ and sample origin $(\mathrm{Q}=23.95, \mathrm{df}=3, p<.001)$. Table 5 shows effect sizes per instrument used and for each country of origin, indicating significantly different levels of selfreported impulsivity on the EASI and in German and Spanish samples. [Table 5 near here]

Inspection of frequencies revealed that all subscales were named 'impulsivity'. Due to this lack of variance, no moderator analysis was carried out on this 
possible moderator variable. A moderator analysis of judicial phase showed a small significant moderation effect $(\mathrm{Q}=343.62, \mathrm{df}=4, p<.001 ; g=-0.16,95 \% \mathrm{CI}=-0.25-$ 0.07), indicating significantly different levels of self-reported impulsivity between forensic populations and reference groups. Only one out of the eight studies featured both forensic scores and reference scores of a non-incarcerated sample. Results of the moderator analysis showed a small significant moderation effect $(\mathrm{Q}=8.02, \mathrm{df}=1, p<$ $.001 ; g=0.38,95 \% \mathrm{CI}=0.03-0.74)$ with effect sizes indicating different levels of selfreported impulsivity in forensic populations when compared to simultaneously created reference scores of a non-incarcerated sample. Regarding gender, results showed no significant effect on self-reported levels of impulsivity $(\mathrm{Q}=1.64, \mathrm{df}=1, p=.20 ; g=$ $0.09,95 \% \mathrm{CI}=-0.28-0.47)$. A moderator analysis for type of crime revealed a moderately significant effect $(\mathrm{Q}=18.22, \mathrm{df}=3, p<.001 ; g=0.51,95 \% \mathrm{CI}=0.38-$ 0.63). It also showed that forensic populations who were incarcerated for capital crimes and a mix of various categories of felonies, misdemeanours, and violations display different levels of self-reported impulsivity, when compared to non-forensic populations. Type of crime was not specified in four of the studies focusing on impulsivity. All effect sizes are shown in Table 5.

Meta-regression analysis on mean age of the forensic sample showed a small significant effect (Coeff. $=-.15, p=.04$ ), indicating that levels of self-reported impulsivity decrease with age. Year of study showed no significant effect (Coeff. $=-.07$, $p=.24)$. Inspection of the funnel plot for publication bias indicated the unlikelihood of a meaningful publication bias.

\section{Quality of studies}

Methodological quality of the included studies was assessed independently by two of the authors (MS and MLM). Agreement among assessments (performed in STATA version 
13; StataCorp, 2013) proved to be good at total NOS quality score level (73\% agreement, Cohen's $K=0.57, \mathrm{SE}=0.10, p<.001)$ and at item level $(91 \%$ agreement, $K=0.84, \mathrm{SE}=$ $0.04, p<.001)$. Methodological quality of the studies was not associated with outcome at the level of statistical significance (Pearson's $r=.12, p=.20$, Spearman's $\rho=.13, p=$ $.19)$.

\section{Discussion}

The current study is, to the authors' knowledge, the first comprehensive meta-analytic review of self-reported severe variants of common personality dimensions - anger, aggression, hostility, antisocial traits, psychopathy, and impulsivity - carried out in forensic populations and compared to non-forensic norm or reference groups. This study found no overall differences in self-reported levels of anger, aggression, hostility, or impulsivity between the general or healthy population and forensic samples. It did find varying levels - both low and high - of self-reported anger, aggression, and hostility scores depending on what instrument or subscale was used and significantly decreasing levels of self-reported impulsivity with age. Self-reported antisocial and psychopathic features were significantly and substantially higher in forensic samples than in reference groups. Simultaneously, levels of these personality traits also varied per instrument and subscale. Levels of all studied personality traits also often varied with country of origin, gender, and judicial phase.

Results of moderation analyses suggest that a number of factors may influence self-reported severe variants of common personality dimensions, including assessment instrument and subscale used, country of sample origin, gender, judicial phase, type of crime, and source of the control or reference scores for self-reported levels of antisocial and psychopathic traits. However, due to the small number of studies in some of the groups, interpreting these results must be met with caution. 
Consistent with the present study, previous research shows that self-reports of impulsivity as well as sensation-seeking and risk-taking decrease with age (Arnett, 1994; Galvan, Hare, Voss, Glover, \& Casey, 2007; Leshem \& Glicksohn, 2007; Steinberg, Albert, Cauffman, Banich, Graham, \& Woolard, 2008). Also, studies have shown gender differences (Costa, Terracciano, \& McCrae, 2001; Del Giudice, Booth, Irwing, 2012; Weisberg, DeYoung, \& Hirsh, 2011) as well as cross-cultural differences in personality traits, such as higher mean scores on the MMPI-2 in Israeli samples than in American samples (Almagor \& Nevo, 1996).

In the current study, levels of self-reported antisocial and psychopathic features were higher in forensic samples than in reference groups. This effect appeared to be especially large in studies that used the MMPI (54\%) compared to studies using other instruments. Further inspection of this self-report personality assessment instrument revealed that the Psychopathic deviate (Pd) scale of the MMPI does not directly assess psychopathic or antisocial features but is made up of five rather heterogeneous subscales. These not only measure the antisocial constructs of social imperturbability and authority conflict but also problems with interpersonal relationships and impulse control, as well as social and self-alienation (Butcher, Hass, Greene, \& Nelson, 2015). High scores on the Pd scale in the current study could, in theory, be due to other issues pertaining to social maladjustment. Unfortunately, the majority of the articles used in the current study only mentioned scores on the Pd scale as a whole. Therefore, precise scores per Pd subscale could not be investigated further to further analyse which subscale(s) in particular contributed to the high Pd score.

When considering the high levels of self-reported antisocial and psychopathic features found in the current study, one might wonder which came first: high levels of these traits or a prison sentence? Perhaps these traits worsen the longer an individual is 
imprisoned? This was in fact discussed by Adams (1976) in one of the oldest articles used in the current meta-analysis, when considering recidivism and high scores on the MMPI's psychopathic deviate scale: does each imprisonment only serve to worsen antisocial attitudes and continue the recidivistic cycle? Findings by Osberg and Poland (2001) also indicate that specific characteristics of psychopathy are related to history of previous crime in a sample of inmates in a maximum-security prison: problems with authority, self-alienation, and familial discord. A range of research, however, strongly supports the association between the antisocial lifestyle that is characteristic of antisocial personality disorder and psychopathy and a high rate of imprisonment (including Black, Gunter, Loveless, Allen, \& Sieleni, 2010; Fazel \& Danesh, 2002; Hare, 2006; Neumann \& Hare, 2008). It could be the case that higher levels of antisocial and psychopathic traits, and consequently a more profound antisocial lifestyle, lead to higher prison sentences for offenders.

Previous studies have found under(self-)reporting of aggression and hostility (Hornsveld, Muris, Kraaimaat, \& Meesters, 2009) and overall personality pathology (Spaans et al., 2015) in forensic samples. The lack of significant differences in levels of anger, aggression, hostility, or impulsivity between forensic and non-forensic populations in the current study could be due to the use of self-report instruments in forensic settings. Several authors have voiced concerns about the use of self-report data within forensic samples (Edens, 2009; Milton et al., 2005; Spaans et al., 2009) as they may yield underestimations of the actual level of forensically relevant personality traits due to their sensitivity to bias from a social desirable response tendency in prison inmates. This tendency to give positive self-descriptions (Paulhus, 2002) includes intentional positive impression management and faking good (presenting oneself in a positive light) and unintentional self-deception (Ray, Hall, Poythress, Rivera-Hudson, \& Lilienfeld, 2013) on 
items that clearly describe a negative trait. Possible aims are to gain advantages such as a lower prison sentence or to avoid enforced treatment. The lower than expected levels of anger, aggression, hostility, and impulsivity in forensic samples could in theory be due to this tendency.

On the other hand, previous research comparing self-report assessment with interview or observer-rated methods to establish their convergence for the diagnosis of personality disorder has yielded conflicting results about antisocial and psychopathic personality traits. De Ruiter and Greeven (2000), for example, found that Cluster B personality disorder was underreported on a self-report instrument compared to interview methods in a forensic sample. Hilderbrand and De Ruiter (2004) concluded that this was most likely due to the lack of self-awareness of any symptoms and defensiveness that is inherent to Cluster B personality disorders. Zimmerman and Coryell (1990) and Blackburn, Donnelly, Logan, and Renwick (2004) also found underreporting of passiveaggressive and antisocial personality disorder, respectively, in self-report instruments in a forensic sample. These findings do not concur with the present finding of higher levels of antisocial and psychopathic features in forensic samples and regrettably bring us no closer to an explanation of the current findings. It could be the case that lack of insight into one's own symptoms and a social desirable response tendency diminish differences in levels of self-reported severe variants of common personality dimensions between forensic and non-forensic groups, and that only large differences 'survive' this overall diminishing effect. This would explain the significantly higher levels of self-reported antisocial and psychopathic features in forensic samples, despite the above-mentioned response tendencies.

The results of the current study add to existing doubts about the validity of the self-report method for assessing deviant or disruptive personality traits. The 
differences per instrument used to assess self-reported anger, aggression, and hostility indicate the importance of finding a universal instrument and terminology that is suitable for the forensic field. Divergent results in forensic samples concerning distorted response styles such as positive impression management, especially in the assessment of antisocial and psychopathic personality traits, indicate the need for further research to determine the levels of severe variants of common personality traits in forensic samples. It might be the case that different kinds of deviant response styles apply to different personality traits, whereas it has also been found to be related to possible (legal) consequences (Cima, Pantus, \& Dams, 2007; Walters, 1988). Further research should be conducted by applying a range of self-report instruments, standardized clinical interviews, and observer-rated assessment methods to examine if the personality traits anger, aggression, hostility, antisocial traits, psychopathy, and impulsivity are all forensically relevant if self-report methods do not uncover all of them in forensic populations. It is important to determine the most appropriate method of reliably assessing levels of the various forensically relevant personality traits in forensic samples, while keeping in mind response styles, such as positive impression management, that may distort results.

\section{Limitations}

A limitation of the current study is that only five out of 39 studies featured means and standard deviations of self-reported levels of severe variants of common personality traits belonging to non-imprisoned samples along with those of a forensic population. This led to the necessity of consulting general normative scores in order to compare forensic samples to reference samples. Even though year of study, gender, and country of origin were matched as much as possible, results may have been influenced by the use of these reference scores instead of scores from the same sample. In some cases where the 
normative scores could not be accessed through several channels, other samples than normative samples were consulted.

The three overarching categories of personality traits, in which results from 32 different subscales or constructs were grouped, were closely based on research by Miller and Lynam (2001; 2003; 2015), Miller and colleagues (2001), and Widiger and Costa (2012), with one category representing general features of antisocial and psychopathic behaviour and the others representing agreeableness and conscientiousness, respectively. However, according to Krueger, Derringer, Markon, Watson, and Skodol (2012), some personality traits clearly belong to only one domain while others, may share features of more than one domain. For example, in the current study, dominance was included in the Antisocial/Psychopathy category. High dominance was previously found to be a characteristic of aggressive and antisocial individuals (Dolan \& Blackburn, 2006; Doyle \& Dolan, 2006). Perhaps if dominance had been placed in the Anger/Aggression/ Hostility category, results may have been different. Edens (2009), in a study included in the current meta-analysis, reported higher levels of self-reported dominance in prison inmates than both community and clinical normative samples.

\section{Conclusion}

The current study suggests that forensic professionals should be cautious of the use of self-report instruments to determine levels of severe variants of common personality traits, as results may be prone to bias due to intentional impression management or unintentional self-deception. They should rather base conclusions on a combination of different assessment methods. 


\section{References}

References marked with an asterisk indicate studies included in the meta-analysis.

*Adams, T. C. (1976). Some MMPI differences between first and multiple admissions within a state prison population. Journal of Clinical Psychology, 32(3), 555-558. Retrieved from http://onlinelibrary.wiley.com/journal/10.1002/(ISSN)1097-4679

Almagor, M. \& Nevo, B. (1996). The MMPI-2: Translation and first steps in its adaptation into Hebrew. In: J. N. Butcher (Ed), International adaptations of the MMPI-2: Research and clinical applications (pp. 487-505). Minneapolis, MN: University of Minnesota Press.

American Psychiatric Association (2000). Diagnostic and Statistical Manual of mental disorders (4th ed., text rev.). Washington, D.C.: American Psychiatric Association. American Psychiatric Association (2013). Diagnostic and Statistical Manual of mental disorders: DSM-5. Washington, D.C.: American Psychiatric Association.

Arnett, J. (1994). Sensation seeking: A new conceptualization and a new scale. Personality and Individual Differences, 16, 289-296. Retrieved from http://www.sciencedirect.com/science/article/pii/0191886994901651

Barratt, E. S. (1985). Impulsiveness subtraits: Arousal and information processing. In: J.

T. Spence, C. E. Itard (Eds.), Motivation, emotion, and personality (pp. 137-146). Amsterdam: Elsevier.

*Bauer, G. E. \& Clark, J. A. (1976). Personality deviancy and prison incarceration. Journal of Clinical Psychology, 32(2), 279-283. Retrieved from http://onlinelibrary.wiley.com/journal/10.1002/(ISSN)1097-4679

*Blagov, P. S., Patrick, C. J., Lilienfeld, S. O., Powers, A. D., Phifer, J. E., Venables, N., ... Cooper, G. (2011). Personality constellations in incarcerated psychopathic 
men. Personality Disorders: Theory, Research, and Treatment, 2(4), 293-315. doi:10.1037/a0023908

Black, D. W., Gunter, T., Loveless, P., Allen, J., \& Sieleni, B. (2010). Antisocial personality disorder in incarcerated offenders: Psychiatric comorbidity and quality of life. Annals of Clinical Psychiatry, 22(2), 113-120. Retrieved from http://www.springer.com/medicine/psychiatry/journal/10442

Blackburn, R., Donnelly, J. P., Logan, C., \& Renwick, S. J. D. (2004). Convergent and discriminant validity of interview and questionnaire measures of personality disorder in mentally disordered offenders: A multitrait-multimethod analysis using confirmatory factor analysis. Journal of Personality Disorders, 18(2), 129150. Retrieved from http://www.guilford.com/journals/Journal-of-PersonalityDisorders/Krueger-Livesley/0885579X

*Boccaccini, M. T., Murrie, D. C., Hawes, S. W., Simpler, A., \& Johnson, J. (2010). Predicting recidivism with the Personality Assessment Inventory in a sample of sex offenders screened for civil commitment as sexually violent predators. Psychological Assessment, 22(1), 142-148. doi:10.1037/a0017818

Borenstein, M., Hedges, L.V., Higgins, J.P.T. \& Rothstein, H.R. (2005). Comprehensive Meta-Analysis, Version 2. Englewood, NJ: Biostat.

Buss, A. H. \& Durkee, A. (1957). An inventory for assessing different kinds of hostility. Journal of Consulting Psychology, 21(4), 343-349. doi:10.1037/h0046900

Buss, A. H. \& Perry, M. P. (1992). The Aggression Questionnaire. Journal of Personality and Social Psychology, 63, 452-459. doi:10.1037/0022-3514.63.3.452

Buss, A. H. \& Plomin, R. (1975). A temperament theory of personality development. New York: John Wiley. 
Butcher, J. N., Hass, G.A., Greene, R. L., \& Nelson, L. D. (2015). Using the MMPI-2 in forensic assessment. Washington, DC: American Psychological Association.

Cima, M., Pantus, M., \& Dams, L. (2007). Simulation und Dissimulation in Abhängigkeit vom strafrechtlichen Kontext und der Persönlichkeit. [Simulation and dissimulation in relation to criminal context and personality]. Praxis der Rechtspsychologie, 17(1), 47-62. Retrieved from http://www.praxisderrechtspsychologie.de/

*Claes, L., Tavernier, G., Roose, A., Bijttebier, P., Smith, S. F., \& Lilienfeld, S. O. (2014). Identifying personality subtypes based on the Five-Factor Model Dimensions in male prisoners: Implications for psychopathy and criminal offending. International Journal of Offender Therapy and Comparative Criminology, 58(1), 41-58. doi:10.1177/0306624X12462013

Clark, L. A. (1996). Schedule for Nonadaptive and Adaptive Personality: Manual for administration, scoring, and interpretation. Minneapolis: University of Minnesota Press.

Costa, P. T., \& McCrae, R. R. (1990). Personality disorders and the five-factor model of personality. Journal of Personality Disorders, 4, 362-371.

doi:10.1521/pedi.1990.4.4.362

Costa, P. T. Jr., Terracciano, A., \& McCrae, R. R. (2001). Gender differences in personality traits across cultures: Robust and surprising findings. Journal of Personality and Social Psychology, 81(2), 322-331. doi:10.1037//00223514.81 .2 .322

Cunradi, C. B., Todd, M., Duke, M., \& Ames, G. (2009). Problem drinking, unemployment, and intimate partner violence among a sample of construction 
industry workers and their partners. Journal of Family Violence, 24, 63-74. doi:10.1007/s10896-008-9209-0

*Cuomo, C., Sarchiapone, M., Di Giannantonio, M., Mancini, M., \&Roy, A. (2008). Aggression, impulsivity, personality traits, and childhood trauma of prisoners with substance abuse and addiction. American Journal of Drug and Alcohol Abuse, 34(3), 339-345. doi:10.1080/00952990802010884

Davis, M. H. (1980). A multidimensional approach to individual differences in empathy. JSAS Catalog of Selected Documents in Psychology, 10, 85-104. Retrieved from https://www.eckerd.edu/psychology/iri/

De Ruiter, C., \& Greeven, P. G. J. (2000). Personality disorders in a Dutch forensic sample: Convergence of interview and self-report measures. Journal of Personality Disorders, 14(2), 162-170. Retrieved from http://www.guilford.com/journals/Journal-of-Personality-Disorders/KruegerLivesley/0885579X

Del Giudice, M., Booth, T., Irwing, P. (2012). The distance between Mars and Venus: Measuring global sex differences in personality. PLoS ONE, 7(1), 108. doi:10.1371/journal.pone.0029265

*Dear, G. E., Watt, B. D., \& Dockerill, J. (2003). Factor structure of the Spielberger Anger Expression Scale when used with Australian prisoners. Psychological Reports, 92, 617-620. Retrieved from http://www.amsciepub.com/loi/pr0 Dolan, M., \& Blackburn, R. (2006). Interpersonal factors as predictors of disciplinary infractions in incarcerated personality disordered offenders. Personality and Individual Differences, 40, 897-907. doi:10.1016/j.paid.2005.10.003 
Doyle, H., \& Dolan, M. (2006). Evaluating the validity of anger regulation problems, interpersonal style, and disturbed mental state for predicting inpatient violence. Behavioral Sciences and the Law, 24, 783-798. doi:10.1002/bs1.739

*Echeburúa, E., Fernández-Montalvo, J., \& Amor, P. J. (2003). Psychopathological profile of men convicted of gender violence: a study in the prisons of Spain. Journal of Interpersonal Violence, 18(7), 798-812. doi: $10.1177 / 0886260503253300$

*Edens, J. F. (2009). Interpersonal characteristics of male criminal offenders: personality, psychopathological, and behavioral correlates. Psychological Assessment, 21(1), 89-98. doi:10.1037/a0014856

Edens, J. F., Buffington-Vollum, J. K., Colwell, K.W., Johnson, D.W., \& Johnson, J. K. (2002). Psychopathy and institutional misbehavior among incarcerated sex offenders: A comparison of the Psychopathy Checklist-Revised and the Personality Assessment Inventory. International Journal of Forensic Mental Health, 1, 49-58. doi:10.1080/14999013.2002.10471160

Edwards, A. L. (1959). Edwards Personal Preference Schedule Manual Revised. New York: The Psychological Corporation.

Eysenck, S. B. G., Pearson, P. R., Easting, G., \& Allsopp, J. F. (1985). Age norms for impulsiveness, venturesomeness and empathy in adults. Personality and Individual Differences, 6(5), 613- 619. doi:10.1016/0191-8869(85)90011-X

Fazel, S., \& Danesh, J. (2002) Serious mental disorder in 23000 prisoners: a systematic review of 62 surveys. The Lancet, 359, 545-550. Retrieved from http://www.thelancet.com/

*Fernández-Montalvo, J., Echauri, J. A., Martínez, M., \& Azcárate, J. M. (2012). Batterer men in prison and in court-referred treatment programmes: what is the difference? 
Spanish Journal of Psychology, 15(1), 315-322.

doi:10.5209/rev_.2012.v15.n1.37338

*Firestone, P., Bradford, J. M., Greenberg, D. M., \& Larose, M. R. (1998). Homicidal sex offenders: Psychological, phallometric, and diagnostic features. Journal of the American Academy of Psychiatry and the Law, 26(4), 537-552. Retrieved from http://www.jaapl.org/

Galvan, A., Hare, T., Voss, H., Glover, G., \& Casey, B. J. (2007). Risk taking and the adolescent brain: Who is at risk? Developmental Science, 10, F8-F14. doi:10.1111/j.1467-7687.2006.00579.x

*Haden, S. C. \& Shiva, A. (2008). Trait impulsivity in a forensic inpatient sample: an evaluation of the Barratt impulsiveness scale. Behavioral Sciences and the Law, 26(6), 675-690. doi:10.1002/bs1.820

Hare, R. D. (2006). Psychopathy: A clinical and forensic overview. Psychiatry Clinics of North America, 29, 709-724. doi:10.1016/j.psc.2006.04.007

Hathaway, S. R. \& McKinley, J. C. (1942). The Minnesota Multiphasic Personality Schedule. National Rehabilitation News, 9, 20-22.

Hathaway, S. R. \& McKinley, J. C. (1989). Minnesota Multiphasic Personality Inventory-2: Manual for administration and scoring. Minneapolis, MN: University of Minnesota Press.

*Hepper, E. G., Hart, C. M., Meek, R., Cisek, S., \& Sedikides, C. (2014). Narcissism and empathy in young offenders and non-offenders. European Journal of Personality, 28(2), 201-210. doi:10.1002/per.1939

*Herpertz, S. C., Werth, U., Lukas, G., Qunaibi, M., Schuerkens, A., Kunert, H. J., ... Sass, H. (2001). Emotion in criminal offenders with psychopathy and borderline 
personality disorder. Archives of General Psychiatry, 58(8), 737-745. Retrieved from http://archpsyc.jamanetwork.com/journal.aspx

Hilderbrand, M. \& De Ruiter, C. (2004). PCL-R psychopathy and its relation to DSM-IV Axis I and II disorders in a sample of male forensic psychiatric patients in the Netherlands. International Journal of Law and Psychiatry, 27, 233-248. doi:10.1016/j.ijlp.2004.03.005

*Holland, T. R. \& Holt, N. (1975). Personality patterns among short-term prisoners undergoing presentence evaluations. Psychological Reports, 37(3), 827-836. Retrieved from http://www.amsciepub.com/loi/pr0

Hornsveld, R. H. J., Muris, P., Kraaimaat, F. W., \& Meesters. C. (2009). Psychometric properties of the Aggression Questionnaire in Dutch violent forensic psychiatric patients and secondary vocational students. Assessment, 16, 181-192. doi: $10.1177 / 1073191108325894$

*Hulme, P. A. \& Middleton, M. R. (2013). Psychosocial and developmental characteristics of civilly committed sex offenders. Issues in Mental Health Nursing, 34(3), 141-149. doi: 10.3109/01612840.2012.732193

*Hurt, S., \& Oltmanns, T. F. (2002). Personality traits and pathology in older and younger incarcerated women. Journal of Clinical Psychology, 58(4), 457-464. doi:10.1002/jclp.1155

*Iliceto, P., Pompili, M., Candilera, G., Rosafio, I., Erbuto, D., Battuello, M., Girardi, P. (2012). Temperament, insecure attachment, impulsivity, and sexuality in women in jail. Journal of Forensic Nursing, 8(1), 23-29. doi:10.1111/j.19393938.2011.01127.x 
*Kalichman, S. C. (1990). Affective and personality characteristics of MMPI profile subgroups of incarcerated rapists. Archives of Sexual Behavior, 19(5), 443-459. Retrieved from http://link.springer.com/journal/10508

*Knust, S. \& Stewart, A. L. (2002). Risk-taking behaviour and criminal offending: an investigation of sensation seeking and the Eysenck personality questionnaire. International Journal of Offender Therapy and Comparative Criminology, 46(5), 586-602. doi:10.1177/030662402236742

*Kroner, D. G., \& Reddon, J. R. (1992). The Anger Expression Scale and State-Trait Anger Scale. Stability, reliability, and factor structure in an inmate sample. Criminal Justice and Behavior, 19(4), 397-408. Retrieved from http://cjb.sagepub.com/

Krueger, R. F., Derringer, J., Markon, K. E., Watson, D., \& Skodol, A. E. (2012). Initial construction of a maladaptive personality trait model and inventory for DSM-5. Psychological Medicine, 42(9), 1879-1890. doi:10.1017/S0033291711002674

*Laulik, S., Allam, J., \& Sheridan, L. (2007). An investigation into maladaptive personality functioning in Internet sex offenders. Psychology, Crime \& Law, 13(5), 523-535. doi:10.1080/10683160701340577

Leshem, R., \& Glicksohn, J. (2007). The construct of impulsivity revisited. Personality and Individual Differences, 43, 681-691. doi:10.1016/j.paid.2007.01.015

*Magaletta, P. R., Faust, E., Bickart, W., \& McLearen, A. M. (2014). Exploring clinical and personality characteristics of adult male internet-only child pornography offenders. International Journal of Offender Therapy and Comparative Criminology, 58(2), 137-153. doi:10.1177/0306624X12465271

*Magyar, M. S., Edens, J. F., Lilienfeld, S. O., Douglas, K. S., Poythress, N. G., \& Skeem, J. L. (2012). Using the Personality Assessment Inventory to predict male 
offenders' conduct during and progression through substance abuse treatment. Psychological Assessment, 24(1), 216-225. doi:10.1037/a0025359

Martin, R., Watson, D., \& Wan, C. K. (2000). A three-factor model of trait anger: Dimensions of affect, behavior, and cognition. Journal of Personality, 68(5), 869897. Retrieved from http://www.ncbi.nlm.nih.gov/pubmed/11001152

*McCreary, C. \& Padilla, E. (1977). MMPI differences among black, Mexican-American and white male offenders. Journal of Clinical Psychology, 33(1), 171-177. Retrieved from http://onlinelibrary.wiley.com/journal/10.1002/(ISSN)1097-4679

Mehrabian, A. \& Epstein, N. (1972). A measure of emotional empathy. Journal of Personality, 40, 525-543. doi:10.1111/j.1467-6494.1972.tb00078.x

Miller, J. D. \& Lynam, D. (2001). Structural models of personality and their relation to antisocial behavior: A meta-analytic review. Criminology, 39, 765-798. doi:10.1111/j.1745-9125.2001.tb00940.x

Miller, J. D. \& Lynam, D. R. (2003). Psychopathy and the Five-Factor Model of Personality: A Replication and Extension. Journal of Personality Assessment, 81(2), 168-178. doi:10.1207/S15327752JPA8102 08

Miller, J. D. \& Lynam, D. R. (2015). Understanding Psychopathy Using the Basic Elements of Personality. Social and Personality Psychology Compass, 9(5), 223237. doi:10.1111/spc3.12170

Miller, J. D., Lynam, D. R., Widiger, T. A., \& Leukefeld, C. (2001). Personality disorders as extreme variants of common personality dimensions. Can the Five-Factor Model of personality adequately represent psychopathy? Journal of Personality, 69, 253-276. Retrieved from http://www.ncbi.nlm.nih.gov/pubmed/11339798

Milton, J., McCartney, M., Duggan, C., Evans, C., Collins, M., McCarthy, L., \& Larkin, E. (2005). Beauty in the eye of the beholder? How high security hospital 
psychopathically-disordered patients rate their own interpersonal behaviour. Journal of Forensic Psychiatry \& Psychology, 16, 552-565.

doi:10.1080/14789940500098194

Morey, L. C. (1991). Personality Assessment Inventory - Professional manual. Lutz: Psychological Assessment Resources, Inc.

Neumann, C. S., \& Hare, R. D. (2008). Psychopathic traits in a large community sample: Links to violence, alcohol use, and intelligence. Journal of Consulting and Clinical Psychology, 76, 893-899. doi:10.1037/0022-006X.76.5.893

*Newberry, M. \& Shuker, R. (2012). Personality assessment inventory (PAI) profiles of offenders and their relationship to institutional misconduct and risk of reconviction. Journal of Personality Assessment, 94(6), 586-592. doi:10.1080/00223891.2012.669220

Norlander, B., \& Eckhardt, C. (2005). Anger, hostility, and male perpetrators of intimate partner violence: A meta-analytic review. Clinical Psychology Review, 25, 119 152. doi:10.1016/j.cpr.2004.10.001

Osberg, T. M., \& Poland, D. L. (2001). Validity of the MMPI-2 basic and Harris-Lingoes subscales in a forensic sample. Journal of Clinical Psychology, 57(12), 13691380. doi:10.1002/jclp.1103

Overall, J. E. \& Gomez-Mont, F. (1974). The MMPI-168 for psychiatric screening. Educational and Psychological Measurement, 34(2), 315-319. doi:10.1177/001316447403400211

*Panton, J. H. (1976). Personality characteristics of death-row prison inmates. Journal of Clinical Psychology, 32(2), 306-309. Retrieved from http://onlinelibrary.wiley.com/journal/10.1002/(ISSN)1097-4679 
Patton, J. H., Stanford, M. S., \& Barratt, E. S. (1995). Factor structure of the Barratt Impulsiveness Scale. Journal of Clinical Psychology, 51(6), 768-74. doi:10.1002/1097-4679(199511)51:6<768::AID-JCLP2270510607>3.0.CO;2-1

Paulhus, D. L. (2002). Socially desirable responding: The evolution of a construct. In: H. I. Braun, D. N. Jackson, \& D. E. Wiley (Eds.), The role of constructs in a psychological and educational measurement (pp.49-46). Mahwah NJ: Erlbaum.

*Percosky, A. B., Boccaccini, M. T., Bitting, B. S., \& Hamilton, P. M. (2013). Personality Assessment Inventory scores as predictors of treatment compliance and misconduct among sex offenders participating in community-based treatment. Journal of Forensic Psychology Practice, 13(3), 192-203. doi:10.1080/15228932.2013.795425

Ray, J. V., Hall, J., Poythress, N. G., Rivera-Hudson, N., \& Lilienfeld, S. O. (2013). The relation between self-reported psychopathic traits and distorted response styles: A meta-analytic review. Personality Disorders: Theory, Research, and Treatment, 4(1), 1-4. doi:10.1037/a0026482

*Reith, G., Crockett, D., \& Craig, K. (1975). Personality characteristics in heroin addicts and nonaddicted prisoners using the Edwards Personality Preference Schedule. The International Journal of the Addictions, 10(1), 97-112. Retrieved from http://informahealthcare.com

*Roman, D. D. \& Gerbing, D. W. (1989). The mentally disordered criminal offender: A description based on demographic, clinical and MMPI data. Journal of Clinical Psychology, 45(6), 983-990. Retrieved from http://onlinelibrary.wiley.com/journal/10.1002/(ISSN)1097-4679

*Roy, A., Carli, V., Sarchiapone, M., \& Branchey, M. (2014). Comparisons of prisoners who make or do not make suicide attempts and further who make one or multiple 
attempts. Archives of Suicide Research, 18(1), 28-38.

doi:10.1080/13811118.2013.801816

*Ruiz, M. A., Cox, J., Magyar, M. S., \& Edens, J. F. (2014). Predictive validity of the personality assessment inventory (PAI) for identifying criminal reoffending following completion of an in-jail addiction treatment program. Psychological Assessment, 26(2), 673-678. doi:10.1037/a0035282

${ }^{*}$ Scott, N. A. \& Conn, M. G. (1979). Correspondence of the MMPI and MMPI-168 among incarcerated female felons. Journal of Personality Assessment, 43(5), 473478. Retrieved from http://www.tandfonline.com/toc/hjpa20/current

Shorey, R. C., Brasfield, H., Febres, J., \& Stuart, G. L. (2011). The association between impulsivity, trait anger, and the perpetration of intimate partner violence among women arrested for domestic violence. Journal of Interpersonal Violence, 26(13), 2681-2697. doi:10.1177/0886260510388289

*Shechory, M., Weiss, J. M., Weinstain, R. (2013). Differentiating offenders by index offense and personality inventories: The characteristics of adult probationers in Israel. International Journal of Offender Therapy and Comparative Criminology, 57(3), 312-331. doi:10.1177/0306624X11428316

Spaans, M., Barendregt, M., Muller, E., De Beurs, E., Nijman, H., \& Rinne, T. (2009). MMPI profiles of males accused of severe crimes: A cluster analysis. Psychology, Crime \& Law, 15(5), 441-450. doi:10.1080/10683160802356704

Spaans, M., Rinne, T., De Beurs, E, \& Spinhoven, P. (2015). The DAPP-SF as a screener for personality disorder in a forensic setting. Journal of Personality Assessment, 97(2), 172-181. doi:10.1080/00223891.2014.976866

Spielberger, C. D. (1988). Manual for the State-Trait Anger Expression Inventory (STAXI). Odessa, FL: Psychological Assessment Resources, Inc. 
Spielberger, C. D., Jacobs, G., Russel, S., \& Crane, R. S. (1983). Assessment of anger: The State-Trait Anger Scale. In: J. N. Butcher and C. D. Spielberger (Eds.), Advances in personality assessment, Vol. 2 (pp. 161-189). Hillsdale, NJ: Lawrence Erlbaum Associates.

Spielberger, C. D., Johnson, E. H., Jacobs, G. A., Krasner, S. S., Oesterle, S. E., \& Worden, T. J. (1986). The Anger Expression (AX) Scale. Tampa: University of South Florida Human Resources Institute.

StataCorp, 2013. Stata Statistical Software: Release 13. College Station, TX: StataCorp LP.

Steinberg, L., Albert, D., Cauffman, E. Banich, M., Graham, S., \& Woolard, J. (2008). Age differences in sensation seeking and impulsivity as indexed by behavior and self-report: Evidence for a dual systems model. Developmental Psychology, 44(6), 1764-1778. doi:10.1037/a0012955

Taft, C. T., O’Farrell, T., Torres, S. E., Panuzio, J., Monson, C. M., Murphy, M., Murphy, C. M. (2006). Examining the correlates of psychological aggression among a community sample of couples. Journal of Family Psychology, 20, 581588. doi:10.1037/0893-3200.20.4.581

*Twomey, J. F. \& Hendry, C. H. (1969). MMPI characteristics of difficult-to-manage federal penitentiary offenders. Psychological Reports, 24(2), 546. Retrieved from http://www.amsciepub.com/loi/pr0

*Valliant, P. M., De Wit M., \& Bowes, R. (2004). Cognitive and personality factors associated with assaultive and domestic offenders. Psychological Reports, 94(3), 1180-1184. Retrieved from http://www.amsciepub.com/loi/pr0

*Valliant, P. M., Gauthier, T., Pottier, D., \& Kosmyna, R. (2000). Moral reasoning, interpersonal skills, and cognition of rapists, child molesters, and incest offenders. 
Psychological Reports, 86(1), 67-75. Retrieved from

http://www.amsciepub.com/loi/pr0

Walters, G. D. (1988). Assessing dissimulation and denial on the MMPI in a sample of maximum security, male inmates. Journal of Personality Assessment, 52(3), 465474. Retrieved from http://www.tandfonline.com/toc/hjpa20/current

Walters, G. D. (2007). Predicting Institutional Adjustment With the Lifestyle Criminality Screening Form and the Antisocial Features and Aggression Scales of the PAI. Journal of Personality Assessment, 88(1), 99-105.

doi:10.1080/00223890709336840

*Walls, R., McGlynn, F. D., \& Tingstrom, D. H. (1977). An evaluation of three short forms extracted from the group form MMPI responses in incarcerated offenders. Journal of Clinical Psychology, 33(2), 431-435. Retrieved from http://onlinelibrary.wiley.com/journal/10.1002/(ISSN)1097-4679

Weisberg, Y. J., DeYoung, C. G., \& Hirsh, J. B. (2011). Gender differences in personality across the ten aspects of the Big Five. Frontiers in Psychology, 2, 178. doi:10.3389/fpsyg.2011.00178

Wells, G. A., Shea, B., O'Connell, D., Peterson, J., Welch, V., Losos, M., \& Tugwell, P. The Newcastle-Ottawa Scale (NOS) for assessing the quality non-randomised studies in meta-analyses. Ottawa Healthcare Institute. Retrieved from http://www.ohri.ca/programs/clinical_epidemiology/oxford.asp on July 15, 2015.

Widiger, T. A., \& Costa, P. T. (2012). Integrating Normal and Abnormal Personality Structure: The Five-Factor Model. Journal of Personality, 80, 1471-1506. doi:10.1111/j.1467-6494.2012.00776.x

Zimmerman, M., \& Coryell, W. H. (1990). Diagnosing personality disorders in the community: A comparison of self-report and interview measures. Archives of 
General Psychiatry, 47, 527-531. Retrieved from

http://archpsyc.jamanetwork.com/journal.aspx 
Appendix 1. Search terms

Prisons[MeSH] OR Prisoners[MeSH] OR Incarcerat*[ti] OR Probati*[ti] OR Prison*[ti] OR Imprison*[ti] OR Jail*[ti] OR Inmat*[ti] OR Penitent*[ti] OR Detention*[ti] OR Detain*[ti] OR Probati*[ti] OR Incarcerat*[ti] OR Gaol*[ti] OR ((Penal*[ti] OR Correct*[ti]) AND (Institut*[ti] OR System*[ti]))) AND (Personality[MeSH] OR Mental Health[MeSH] OR Personality[ti] OR Personalities[ti] OR Assertiven*[ti] OR Authoritarianis*[ti] OR Character*[ti] OR Creativity[ti] OR Dependency[ti] OR Empath*[ti] OR Individuality[ti] OR Intelligence[ti] OR IQ[ti] OR Leadership*[ti] OR Machiavellianis*[ti] OR Negativis*[ti] OR Ego[ti] OR Extravers*[ti] OR Identification[ti] OR Identity[ti] OR Identities[ti] OR Individuation[ti] OR Introversi*[ti] OR "Moral Development"[ti] OR "Psychosexual Develop*"[ti] OR "Self Concept*"[ti] OR Superego[ti] OR Unconscious[ti] OR Temperament*[ti] OR Mental Health*[ti] 
Appendix 2. Flow diagram of search process

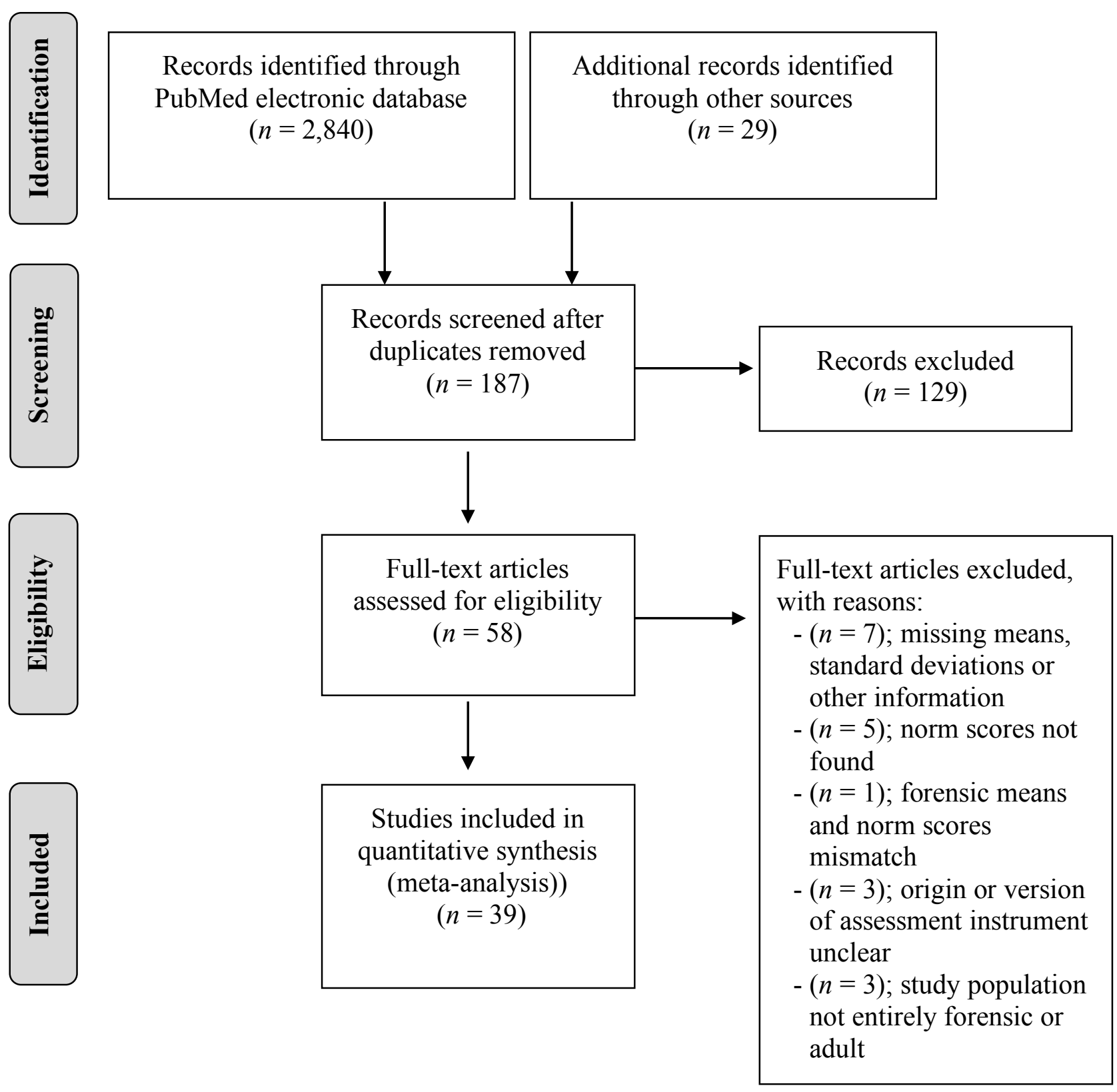


Table 1. Personality trait categories and corresponding instruments and subscales

\begin{tabular}{|c|c|c|c|}
\hline Category & Subscale & Instrument & Study name(s) \\
\hline \multirow[t]{13}{*}{$\begin{array}{l}\text { Anger/ } \\
\text { Aggression/ } \\
\text { Hostility }\end{array}$} & Aggression & $\begin{array}{l}\text { EPPS } \\
\text { (Edwards } \\
1959)\end{array}$ & 1. Reith et al. 1975 \\
\hline & Aggression & $\begin{array}{l}\text { PAI } \\
\text { (Morey 1991) }\end{array}$ & $\begin{array}{l}\text { 1. Boccaccini et al. } 2010 \\
\text { 2. Haden \& Shiva } 2008 \\
\text { 3. Laulik et al. } 2007 \\
\text { 4. Magaletta et al. } 2014 \\
\text { 5. Magyar et al. } 2012 \\
\text { 6. Newberry \& Shuker } 2012 \\
\text { 7. Percosky et al. } 2013 \\
\text { 8. Ruiz et al. } 2014\end{array}$ \\
\hline & Aggression & $\begin{array}{l}\text { SNAP } \\
\text { (Clark 1996) }\end{array}$ & 1. Hurt \& Oltmanns 2002 \\
\hline & Anger & $\begin{array}{l}\text { AQ } \\
\text { (Buss \& Perry } \\
1992 \text { ) }\end{array}$ & 1. Hulme \& Middleton 2013 \\
\hline & Anger in & $\begin{array}{l}\text { AX } \\
\text { (Spielberger } \\
\text { Johnson, } \\
\text { Jacobs } \\
\text { Krasner } \\
\text { Oesterle \& } \\
\text { Worden 1986) }\end{array}$ & $\begin{array}{l}\text { 1. Dear et al. } 2003 \\
\text { 2. Kalichman } 1990 \\
\text { 3. Kroner \& Reddon } 1992\end{array}$ \\
\hline & Anger out & $\begin{array}{l}\text { AX } \\
\text { (Spielberger } \\
\text { et al. 1986) } \\
\end{array}$ & $\begin{array}{l}\text { 1. Dear et al.2003 } \\
\text { 2. Kalichman } 1990 \\
\text { 3. Kroner \& Reddon } 1992\end{array}$ \\
\hline & Anger control & $\begin{array}{l}\text { AX } \\
\text { (Spielberger } \\
\text { et al. 1986) }\end{array}$ & $\begin{array}{l}\text { 1. Dear et al. } 2003 \\
\text { 2. Kalichman } 1990 \\
\text { 3. Kroner \& Reddon } 1992\end{array}$ \\
\hline & Anger control & $\begin{array}{l}\text { STAXI } \\
\text { (Spielberger } \\
1988)\end{array}$ & $\begin{array}{l}\text { 1. Blagov et al. } 2011 \\
\text { 2. Fernández-Montalvo et al. } 2012 \\
\text { 3. Roy et al. } 2014\end{array}$ \\
\hline & Anger in & $\begin{array}{l}\text { STAXI } \\
\text { (Spielberger } \\
1988) \\
\end{array}$ & $\begin{array}{l}\text { 1. Blagov et al. } 2011 \\
\text { 2. Fernández-Montalvo et al. } 2012 \\
\text { 3. Roy et al. } 2014\end{array}$ \\
\hline & Anger out & $\begin{array}{l}\text { STAXI } \\
\text { (Spielberger } \\
1988 \text { ) }\end{array}$ & $\begin{array}{l}\text { 1. Blagov et al. } 2011 \\
\text { 2. Fernández-Montalvo et al. } 2012 \\
\text { 3. Roy et al. } 2014\end{array}$ \\
\hline & Hostility & $\begin{array}{l}\text { BDHI } \\
\text { (Buss \& } \\
\text { Durkee 1957) }\end{array}$ & $\begin{array}{l}\text { 1. Firestone et al. } 1998 \\
\text { 2. Knust \& Stewart } 2002 \\
\text { 3. Roy et al. } 2014\end{array}$ \\
\hline & Hostility & $\begin{array}{l}\text { AQ } \\
\text { (Buss \& Perry } \\
1992 \text { ) }\end{array}$ & 1. Hulme \& Middleton 2013 \\
\hline & $\begin{array}{l}\text { Physical } \\
\text { aggression }\end{array}$ & $\begin{array}{l}\text { AQ } \\
\text { (Buss \& Perry } \\
1992 \text { ) }\end{array}$ & 1. Hulme \& Middleton 2013 \\
\hline
\end{tabular}




\begin{tabular}{|c|c|c|c|}
\hline & Trait anger & $\begin{array}{l}\text { STAS } \\
\text { (Spielberger } \\
\text { Jacobs Russel } \\
\text { \& Crane, } \\
\text { 1983) }\end{array}$ & $\begin{array}{l}\text { 1. Kalichman } 1990 \\
\text { 2. Kroner \& Reddon } 1992\end{array}$ \\
\hline & Trait anger & $\begin{array}{l}\text { STAXI } \\
\text { (Spielberger } \\
1988)\end{array}$ & $\begin{array}{l}\text { 1. Echeburúa et al. } 2003 \\
\text { 2. Fernández-Montalvo et al.2012 } \\
\text { 3. Shorey et al. } 2011\end{array}$ \\
\hline & $\begin{array}{l}\text { Trait anger } \\
\text { reaction }\end{array}$ & $\begin{array}{l}\text { STAXI } \\
\text { (Spielberger } \\
1988 \text { ) }\end{array}$ & 1. Fernández-Montalvo et al. 2012 \\
\hline & $\begin{array}{l}\text { Trait anger } \\
\text { temperament }\end{array}$ & $\begin{array}{l}\text { STAXI } \\
\text { (Spielberger } \\
1988)\end{array}$ & 1. Fernández-Montalvo et al. 2012 \\
\hline & $\begin{array}{l}\text { Verbal } \\
\text { aggression }\end{array}$ & $\begin{array}{l}\text { AQ } \\
\text { (Buss \& Perry } \\
1992 \text { ) }\end{array}$ & 1. Hulme \& Middleton 2013 \\
\hline $\begin{array}{l}\text { Antisocial/ } \\
\text { Psychopathy }\end{array}$ & $\begin{array}{l}\text { Antisocial } \\
\text { features }\end{array}$ & $\begin{array}{l}\text { PAI } \\
\text { (Morey 1991) }\end{array}$ & $\begin{array}{l}\text { 1. Boccaccini et al. } 2010 \\
\text { 2. Edens } 2009 \\
\text { 3. Haden \& Shiva } 2008 \\
\text { 4. Laulik et al. } 2007 \\
\text { 5. Magaletta et al. } 2014 \\
\text { 6. Magyar et al. } 2012 \\
\text { 7. Newberry \& Shuker } 2012 \\
\text { 8. Percosky et al. } 2013 \\
\text { 9. Ruiz et al. } 2014\end{array}$ \\
\hline & Dominance & $\begin{array}{l}\text { EPPS } \\
\text { (Edwards } \\
1959)\end{array}$ & 1. Reith et al. 1975 \\
\hline & Dominance & $\begin{array}{l}\text { PAI } \\
\text { (Morey 1991) }\end{array}$ & $\begin{array}{l}\text { 1. Boccaccini et al. } 2010 \\
\text { 2. Edens } 2009 \\
\text { 3. Laulik et al. } 2007 \\
\text { 4. Magaletta et al. } 2014 \\
\text { 5. Magyar et al. } 2012 \\
\text { 6. Newberry \& Shuker } 2012 \\
\text { 7. Percosky et al. } 2013 \\
\text { 8. Ruiz et al. } 2014\end{array}$ \\
\hline & $\begin{array}{l}\text { Empathic } \\
\text { concern }\end{array}$ & $\begin{array}{l}\text { IRI } \\
\text { (Davis 1980) }\end{array}$ & 1. Hepper et al. 2014 \\
\hline & Empathy & $\begin{array}{l}\text { BEES } \\
\text { (Mehrabian \& } \\
\text { Epstein 1972) }\end{array}$ & 1. Hulme \& Middleton 2013 \\
\hline & $\begin{array}{l}\text { Manipulativen } \\
\text { ess }\end{array}$ & $\begin{array}{l}\text { SNAP } \\
\text { (Clark 1996) }\end{array}$ & 1. Hurt \& Oltmanns 2002 \\
\hline & $\begin{array}{l}\text { Psychopathic } \\
\text { deviate }\end{array}$ & $\begin{array}{l}\text { MMPI-1 } \\
\text { (Hathaway \& } \\
\text { McKinley } \\
\text { 1942) }\end{array}$ & $\begin{array}{l}\text { 1. Adams } 1976 \\
\text { 2. Bauer \& Clark } 1976 \\
\text { 3. Holland \& Holt } 1975 \\
\text { 4. Kalichman } 1990 \\
\text { 5. McCreary \& Padilla } 1977 \\
\text { 6. Panton } 1976\end{array}$ \\
\hline
\end{tabular}




\begin{tabular}{|c|c|c|c|}
\hline & & & $\begin{array}{l}\text { 7. Roman \& Gerbing } 1989 \\
\text { 8. Scott \& Conn } 1979 \\
\text { 9. Twomey \& Hendry } 1969 \\
\text { 10. Walls et al. } 1977\end{array}$ \\
\hline & $\begin{array}{l}\text { Psychopathic } \\
\text { deviate }\end{array}$ & $\begin{array}{l}\text { MMPI-168 } \\
\text { Overall \& } \\
\text { Gomez-Mont } \\
1974)\end{array}$ & $\begin{array}{l}\text { 1. Scott \& Conn } 1979 \\
\text { 2. Valliant et al. } 2000 \\
\text { 3. Valliant et al. } 2004 \\
\text { 4. Walls et al. } 1977\end{array}$ \\
\hline & $\begin{array}{l}\text { Psychopathic } \\
\text { deviate }\end{array}$ & $\begin{array}{l}\text { MMPI-2 } \\
\text { (Hathaway \& } \\
\text { McKinley } \\
1989 \text { ) } \\
\end{array}$ & $\begin{array}{l}\text { 1. Claes et al. } 2014 \\
\text { 2. Shechory et al. } 2013\end{array}$ \\
\hline \multirow[t]{5}{*}{ Impulsivity } & Impulsivity & $\begin{array}{l}\text { EIS } \\
\text { (Eysenck } \\
\text { Pearson } \\
\text { Easting \& } \\
\text { Allsopp 1985) }\end{array}$ & 1. Shorey et al. 2011 \\
\hline & Impulsivity & $\begin{array}{l}\text { BIS-10 } \\
\text { (Barratt 1985) }\end{array}$ & $\begin{array}{l}\text { 1. Echeburúa et al. } 2003 \\
\text { 2. Herpertz et al. } 2001\end{array}$ \\
\hline & Impulsivity & $\begin{array}{l}\text { BIS-11 } \\
\text { (Patton } \\
\text { Stanford } \\
\text { Barratt 1995) }\end{array}$ & $\begin{array}{l}\text { 1. Cuomo et al. } 2008 \\
\text { 2. Haden \& Shiva } 2008 \\
\text { 3. Iliceto et al. } 2012\end{array}$ \\
\hline & Impulsivity & $\begin{array}{l}\text { EASI } \\
\text { Buss \& } \\
\text { Plomin } 1975 \\
\end{array}$ & 1. Blagov et al. 2011 \\
\hline & Impulsivity & $\begin{array}{l}\text { SNAP } \\
\text { (Clark 1996) }\end{array}$ & 1. Hurt \& Oltmanns 2002 \\
\hline
\end{tabular}


Table 2. Articles used in meta-analysis

\begin{tabular}{|c|c|c|}
\hline Study name & Instrument(s) \& subscale(s) & Sample size (n) \\
\hline 1. Adams 1976 & 1. MMPI-1 (psychopathic deviate) & 100 \\
\hline 2. Bauer \& Clark 1976 & 1. MMPI-1 (psychopathic deviate) & 88 \\
\hline 3. Blagov et al. 2011 & $\begin{array}{l}\text { 1. EASI (impulsivity) } \\
\text { 2. STAXI (anger expression in) } \\
\text { 3. STAXI (anger expression out) } \\
\text { 4. STAXI (anger expression } \\
\text { control) }\end{array}$ & $\begin{array}{l}33 \\
34 \\
34 \\
34\end{array}$ \\
\hline 4. Boccaccini et al. 2010 & $\begin{array}{l}\text { 1. PAI (antisocial) } \\
\text { 2. PAI (aggression) } \\
\text { 3. PAI (dominance) }\end{array}$ & $\begin{array}{l}1412 \\
1412 \\
1412 \\
\end{array}$ \\
\hline 5. Claes et al. 2014 & 1. MMPI-2 (psychopathic deviate) & 110 \\
\hline 6. Cuomo et al. 2008 & 1. BIS-11 (total score) & 903 \\
\hline 7. Dear et al. 2003 & $\begin{array}{l}\text { 1. AX (anger in) } \\
\text { 2. AX (anger out) } \\
\text { 3. AX (anger control) }\end{array}$ & $\begin{array}{l}397 \\
397 \\
397\end{array}$ \\
\hline 8. Echeburúa et al. 2003 & $\begin{array}{l}\text { 1. STAXI (trait anger) } \\
\text { 2. BIS-10 (total score) }\end{array}$ & \begin{tabular}{|l|}
54 \\
54 \\
\end{tabular} \\
\hline 9. Edens 2009 & $\begin{array}{l}\text { 1. PAI (antisocial) } \\
\text { 2. PAI (dominance) }\end{array}$ & $\begin{array}{l}1062 \\
1062\end{array}$ \\
\hline $\begin{array}{l}\text { 10. Fernández-Montalvo et } \\
\text { al. } 2012\end{array}$ & $\begin{array}{l}\text { 1. STAXI (trait anger) } \\
\text { 2. STAXI (anger in) } \\
\text { 3. STAXI (anger out) } \\
\text { 4. STAXI (trait anger temperament) } \\
\text { 5. STAXI (trait anger reaction) }\end{array}$ & $\begin{array}{l}123 \\
123 \\
123 \\
123 \\
123 \\
\end{array}$ \\
\hline 11. Firestone et al. 1998 & 1. BDHI (total score) & 96 \\
\hline 12. Haden \& Shiva 2008 & $\begin{array}{l}\text { 1. BIS-11 (total score) } \\
\text { 2. PAI (antisocial) } \\
\text { 3. PAI (aggression) }\end{array}$ & $\begin{array}{l}436 \\
139 \\
139\end{array}$ \\
\hline 13. Hepper et al. 2014 & 1. IRI (empathic concern) & 77 \\
\hline 14. Herpertz et al. 2001 & 1. BIS-10 (total score) & 43 \\
\hline 15. Holland \& Holt 1975 & 1. MMPI-1 (psychopathic deviate) & 295 \\
\hline $\begin{array}{l}\text { 16. Hulme \& Middleton } \\
2013\end{array}$ & $\begin{array}{l}\text { 1. AQ (anger) } \\
\text { 2. AQ (hostility) } \\
\text { 3. AQ (physical aggression) } \\
\text { 4. AQ (verbal aggression) } \\
\text { 5. BEES (empathy) }\end{array}$ & $\begin{array}{l}38 \\
38 \\
38 \\
38 \\
38 \\
\end{array}$ \\
\hline 17. Hurt \& Oltmanns, 2002 & $\begin{array}{l}\text { 1. SNAP (aggression) } \\
\text { 2. SNAP (manipulativeness) } \\
\text { 3. SNAP (impulsivity) }\end{array}$ & $\begin{array}{l}157 \\
157 \\
157 \\
\end{array}$ \\
\hline 18. Iliceto et al. 2012 & 1. BIS-11 (total score) & 40 \\
\hline 19. Kalichman 1990 & $\begin{array}{l}\text { 1. AX (anger in) } \\
\text { 2. AX (anger out) } \\
\text { 3. AX (anger control) } \\
\text { 4. MMPI-1 (psychopathic deviate) } \\
\text { 5. STAS (trait-anger) }\end{array}$ & $\begin{array}{l}111 \\
111 \\
111 \\
111 \\
111 \\
\end{array}$ \\
\hline 20. Knust \& Stewart 2002 & 1. BDHI (total score) & 92 \\
\hline
\end{tabular}




\begin{tabular}{|c|c|c|}
\hline 21. Kroner \& Reddon 1992 & $\begin{array}{l}\text { 1. AX (anger in) } \\
\text { 2. AX (anger out) } \\
\text { 3. AX (anger control) } \\
\text { 4. STAS (trait-anger) }\end{array}$ & $\begin{array}{l}137 \\
137 \\
137 \\
137\end{array}$ \\
\hline 22. Laulik et al. 2007 & $\begin{array}{l}\text { 1. PAI (antisocial) } \\
\text { 2. PAI (aggression) } \\
\text { 3. PAI (dominance) }\end{array}$ & $\begin{array}{l}30 \\
30 \\
30\end{array}$ \\
\hline 23. Magaletta et al. 2014 & $\begin{array}{l}\text { 1. PAI (antisocial) } \\
\text { 2. PAI (aggression) } \\
\text { 3. PAI (dominance) }\end{array}$ & $\begin{array}{l}61 \\
61 \\
61\end{array}$ \\
\hline 24. Magyar et al. 2012 & $\begin{array}{l}\text { 1. PAI (antisocial) } \\
\text { 2. PAI (aggression) } \\
\text { 3. PAI (dominance) }\end{array}$ & $\begin{array}{l}331 \\
331 \\
331\end{array}$ \\
\hline $\begin{array}{l}\text { 25. McCreary \& Padilla } \\
1977\end{array}$ & 1. MMPI-1 (psychopathic deviate) & 304 \\
\hline $\begin{array}{l}\text { 26. Newberry \& Shuker } \\
2012\end{array}$ & $\begin{array}{l}\text { 1. PAI (antisocial) } \\
\text { 2. PAI (aggression) } \\
\text { 3. PAI (dominance) }\end{array}$ & $\begin{array}{l}268 \\
268 \\
268\end{array}$ \\
\hline 27. Panton 1976 & 1. MMPI-1 (psychopathic deviate) & 2585 \\
\hline 28. Percosky et al. 2013 & $\begin{array}{l}\text { 1. PAI (antisocial) } \\
\text { 2. PAI (aggression) } \\
\text { 3. PAI (dominance) }\end{array}$ & $\begin{array}{l}34 \\
34 \\
34\end{array}$ \\
\hline 29. Reith et al.1975 & $\begin{array}{l}\text { 1. EPPS (dominance) } \\
\text { 2. EPPS (aggression) }\end{array}$ & $\begin{array}{l}140 \\
140\end{array}$ \\
\hline 30. Roman \& Gerbing 1989 & 1. MMPI-1 (psychopathic deviate) & 340 \\
\hline 31. Roy et al. 2014 & $\begin{array}{l}\text { 1. BDHI (total score) } \\
\text { 2. STAXI (anger in) } \\
\text { 3. STAXI (anger out) } \\
\text { 4. STAXI (anger control) } \\
\text { 5. STAXI (trait anger) }\end{array}$ & $\begin{array}{l}1537 \\
1537 \\
1537 \\
1537 \\
1537\end{array}$ \\
\hline 32. Ruiz et al. 2014 & $\begin{array}{l}\text { 1. PAI (antisocial) } \\
\text { 2. PAI (aggression) } \\
\text { 3. PAI (dominance) }\end{array}$ & $\begin{array}{l}124 \\
124 \\
124\end{array}$ \\
\hline 33. Scott \& Conn 1979 & $\begin{array}{l}\text { 1. MMPI-1 (psychopathic deviate) } \\
\text { 2. MMPI-168 (psychopathic } \\
\text { deviate) }\end{array}$ & $\begin{array}{l}165 \\
165\end{array}$ \\
\hline 34. Shechory et al. 2013 & 1. MMPI-2 (psychopathic deviate) & 230 \\
\hline 34. Shorey et al. 2011 & $\begin{array}{l}\text { 1. EIS (impulsivity) } \\
\text { 2. STAXI (trait anger) }\end{array}$ & $\begin{array}{l}80 \\
80\end{array}$ \\
\hline $\begin{array}{l}\text { 35. Twomey \& Hendry } \\
1969\end{array}$ & 1. MMPI-1 (psychopathic deviate) & 214 \\
\hline 36. Valliant et al. 2000 & $\begin{array}{l}\text { 1. MMPI-168 (psychopathic } \\
\text { deviate) }\end{array}$ & 54 \\
\hline 37. Valliant et al. 2004 & $\begin{array}{l}\text { 1. MMPI-168 (psychopathic } \\
\text { deviate) }\end{array}$ & 88 \\
\hline 38. Walls et al. 1977 & $\begin{array}{l}\text { 1. MMPI-1 (psychopathic deviate) } \\
\text { 2. MMPI-168 (psychopathic } \\
\text { deviate) }\end{array}$ & $\begin{array}{l}98 \\
98\end{array}$ \\
\hline
\end{tabular}


Note. $\mathrm{AQ}=$ Aggression Questionnaire. $\mathrm{AX}=$ Anger Expression. $\mathrm{BDHI}=$ Buss Durkee Hostility Inventory. BEES = Balanced Emotional Empathy Test. BIS = Barratt Impulsiveness Scale. EASI = Emotionality, Activity, Sociability, and Impulsivity. EIS = Eysenck Impulsiveness Scale. IRI = Interpersonal Reactivity Index. MMPI $=$ Minnesota Multiphasic Personality Inventory. PAI = Personality Assessment Inventory. SNAP = Schedule for Nonadaptive and Adaptive Personality. STAS = State-Trait Anger Scale. STAXI = State-Trait Anger Expression Inventory. 
Table 3. Antisocial/Psychopathy: Results of moderator analyses (27 studies)

\begin{tabular}{|c|c|c|c|c|}
\hline Instrument name & No. of studies & Hedge's g & $95 \%$ CI LL & $95 \%$ CI UL \\
\hline BEES & 1 & 0.14 & -0.23 & 0.51 \\
\hline EPPS & 1 & -0.13 & -0.29 & 0.04 \\
\hline IRI & 1 & $-0.50 * *$ & -0.82 & -0.17 \\
\hline MMPI-1 & 10 & $1.68 * *$ & 1.12 & 2.23 \\
\hline MMPI-168 & 4 & $0.92 * *$ & 0.29 & 1.55 \\
\hline MMPI-2 & 2 & $0.95 * *$ & 0.35 & 1.54 \\
\hline PAI & 9 & $1.05^{* *}$ & 0.68 & 1.43 \\
\hline SNAP & 1 & -0.09 & 0.26 & 0.08 \\
\hline Subscale name & No. of studies & Hedge's g & $95 \%$ CI LL & $95 \%$ CI UL \\
\hline Antisocial features & 9 & $1.05 * *$ & 0.68 & 1.43 \\
\hline Dominance & 9 & -0.13 & -0.29 & 0.04 \\
\hline Empathic concern & 1 & $-0.50 * *$ & -0.82 & -0.17 \\
\hline Empathy & 1 & 0.14 & -0.23 & 0.51 \\
\hline Manipulativeness & 1 & -0.09 & -0.26 & 0.08 \\
\hline Psychopathic Deviate & 14 & $1.38 * *$ & 0.98 & 1.78 \\
\hline Sample origin & No. of studies & Hedge's g & 95\% CI LL & 95\% CI UL \\
\hline Belgium & 1 & $2.14^{* *}$ & 1.79 & 2.49 \\
\hline Canada & 3 & 0.14 & -0.08 & 0.35 \\
\hline Israel & 1 & $0.36^{* *}$ & 0.25 & 0.48 \\
\hline United Kingdom & 3 & 0.44 & -0.49 & 1.37 \\
\hline United States & 19 & $1.50^{* *}$ & 1.13 & 1.87 \\
\hline Gender & No. of studies & Hedge's g & 95\% CI LL & 95\% CI UL \\
\hline Female & 2 & 1.42 & -0.19 & 3.02 \\
\hline Male & 23 & $0.96 * *$ & 0.68 & 1.25 \\
\hline Male and female & 1 & $1.30 * *$ & 1.11 & 1.49 \\
\hline Judicial phase & No. of studies & Hedge's g & $95 \%$ CI LL & $95 \%$ CI UL \\
\hline Convicted & 17 & $1.11^{* *}$ & 0.74 & 1.48 \\
\hline Convicted and in treatment & 3 & $1.30 * *$ & 0.40 & 2.21 \\
\hline $\begin{array}{l}\text { Probationed and in } \\
\text { treatment }\end{array}$ & 2 & $0.35^{* *}$ & 0.24 & 0.46 \\
\hline Remanded and/or convicted & 1 & $0.61 * *$ & 0.54 & 0.69 \\
\hline $\begin{array}{l}\text { Remanded and/or convicted } \\
\text { and in treatment }\end{array}$ & 3 & $1.61^{* *}$ & 1.06 & 2.17 \\
\hline Type of crime & No. of studies & Hedge's g & $95 \%$ CI LL & $95 \%$ CI UL \\
\hline Felonies & 3 & $1.61^{* *}$ & 0.95 & 2.27 \\
\hline Internet sex offenses & 2 & 0.84 & -0.34 & 1.71 \\
\hline Misdeameanours & 1 & $1.87 * *$ & 1.74 & 2.00 \\
\hline Mixed & 8 & $0.58 * *$ & 0.34 & 0.81 \\
\hline Serious offenses & 2 & $1.88^{* *}$ & 1.39 & 2.36 \\
\hline Sex offenses & 4 & $1.66^{* *}$ & 0.81 & 2.50 \\
\hline Source of reference scores & No. of studies & Hedge's g & $95 \%$ CI LL & $95 \%$ CI UL \\
\hline General norms & 24 & $1.15^{* *}$ & 0.86 & 1.43 \\
\hline Original article & 3 & 0.36 & -0.09 & 0.80 \\
\hline
\end{tabular}

Note. $\mathrm{CI}=$ Confidence interval. $\mathrm{LL}=$ Lower limit. $\mathrm{UL}=$ Upper limit.

$*=p<.05 . * *=p<.01$ 
Table 4. Anger/Aggression/Hostility: Results of moderator analyses (21 studies)

\begin{tabular}{|c|c|c|c|c|}
\hline Instrument name & No. of studies & Hedge's g & $95 \%$ CI LL & $95 \%$ CI UL \\
\hline $\mathrm{AQ}$ & 1 & 0.09 & -0.24 & 0.42 \\
\hline $\mathrm{AX}$ & 3 & $0.33 *$ & 0.04 & 0.62 \\
\hline BDHI & 3 & 0.15 & -0.60 & 0.90 \\
\hline EPPS & 1 & $0.35^{* *}$ & 0.13 & 0.58 \\
\hline PAI & 8 & 0.32 & -0.16 & 0.79 \\
\hline SNAP & 1 & $-0.22 *$ & -0.40 & -0.04 \\
\hline STAXI & 5 & $-1.20^{*}$ & -2.05 & -0.36 \\
\hline Subscale name & No. of studies & Hedge's g & $95 \%$ CI LL & $95 \%$ CI UL \\
\hline Aggression & 10 & 0.30 & -0.01 & 0.62 \\
\hline Anger & 1 & 0.09 & -0.24 & 0.42 \\
\hline Anger control & 5 & -0.13 & -0.63 & 0.36 \\
\hline Anger out & 6 & -1.54 & -1.76 & -1.31 \\
\hline Hostility & 4 & 0.15 & -0.60 & 0.90 \\
\hline Trait anger & 7 & -0.64 & -1.33 & 0.05 \\
\hline Sample origin & No. of studies & Hedge's g & $95 \%$ CI LL & 95\% CI UL \\
\hline Australia & 2 & 0.42 & -0.40 & 1.23 \\
\hline Canada & 3 & $0.22 *$ & 0.02 & 0.43 \\
\hline Italy & 1 & $-0.13^{*}$ & -0.24 & -0.02 \\
\hline Spain & 1 & $-1.28 * *$ & -1.80 & -0.75 \\
\hline United Kingdom & 2 & 0.14 & -1.08 & 1.37 \\
\hline United States & 11 & 0.05 & -0.36 & 0.46 \\
\hline Gender & No. of studies & Hedge's g & 95\% CI LL & 95\% CI UL \\
\hline Female & 2 & $-0.25 * *$ & -0.39 & -0.10 \\
\hline Male & 18 & 0.05 & -0.21 & 0.31 \\
\hline Male and female & 1 & $0.91 * *$ & 0.72 & 1.09 \\
\hline Judicial phase & No. of studies & Hedge's g & $95 \%$ CI LL & $95 \%$ CI UL \\
\hline Convicted & 10 & -0.03 & -0.31 & 0.26 \\
\hline Convicted and in treatment & 4 & 0.14 & -0.94 & 1.23 \\
\hline $\begin{array}{l}\text { Probationed and in } \\
\text { treatment }\end{array}$ & 1 & $-0.44 *$ & -0.78 & -0.10 \\
\hline Remanded & 1 & $-0.30^{*}$ & -0.53 & -0.06 \\
\hline Remanded and/or convicted & 3 & 0.19 & -0.22 & 0.59 \\
\hline $\begin{array}{l}\text { Remanded and/or convicted } \\
\text { and in treatment }\end{array}$ & 2 & $0.90 * *$ & 0.78 & 1.03 \\
\hline Type of crime & No. of studies & Hedge's g & $95 \%$ CI LL & 95\% CI UL \\
\hline Gender violence & 1 & $-1.54 * *$ & -1.76 & -1.31 \\
\hline Homicidal sex offense & 1 & -0.20 & -0.64 & 0.24 \\
\hline Mixed & 6 & 0.43 & 0.00 & 0.87 \\
\hline Partner violence & 2 & -0.64 & -1.33 & 0.05 \\
\hline Sex offenders & 5 & 0.11 & -0.26 & 0.47 \\
\hline Source of reference scores & No. of studies & Hedge's g & $95 \%$ CI LL & $95 \%$ CI UL \\
\hline General norms & 20 & 0.03 & -0.22 & 0.28 \\
\hline Original article & 1 & $0.85 * *$ & 0.54 & 1.15 \\
\hline
\end{tabular}

Note. $\mathrm{CI}=$ Confidence interval. $\mathrm{UL}=$ Upper limit. $\mathrm{LL}=$ Lower limit.

$*=p<.05 . * *=p<.01$ 
Table 5. Impulsivity: Results of moderator analyses ( 8 studies)

\begin{tabular}{|l|l|l|l|l|}
\hline Instrument name & No. of studies & Hedge's g & $\mathbf{9 5 \%}$ CI LL & $\mathbf{9 5 \%}$ CI UL \\
\hline BIS-10 & 2 & 0.30 & -0.71 & 1.31 \\
\hline BIS-11 & 3 & -0.27 & -1.33 & 0.79 \\
\hline EASI & 1 & $-1.41^{* *}$ & -1.81 & -1.01 \\
\hline EIS & 1 & 0.19 & -0.05 & 0.42 \\
\hline SNAP & 1 & -0.14 & -0.32 & 0.03 \\
\hline Sample origin & No. of studies & Hedge's g & $\mathbf{9 5 \%}$ CI LL & $\mathbf{9 5 \%}$ CI UL \\
\hline US & 4 & -0.18 & 0.34 & 1.18 \\
\hline Italy (30\%) & 2 & -0.58 & -1.34 & 0.19 \\
\hline Germany & 1 & $0.76^{* *}$ & -0.98 & -0.21 \\
\hline Spain & 1 & $-0.60^{* *}$ & -0.78 & 0.43 \\
\hline Gender & No. of studies & Hedge's g & $\mathbf{9 5 \%}$ CI LL & $\mathbf{9 5 \%}$ CI UL \\
\hline Female & 3 & 0.23 & -0.20 & 0.66 \\
\hline Male & 5 & -0.34 & -1.11 & 0.42 \\
\hline Judicial phase & No. of studies & Hedge's g & $\mathbf{9 5 \%}$ CI LL & $\mathbf{9 5 \%}$ CI UL \\
\hline Convicted & 4 & -0.49 & -1.11 & 0.12 \\
\hline Convicted and in treatment & 1 & $0.76^{* *}$ & 0.34 & 1.18 \\
\hline Remanded and/or convicted & 1 & 0.19 & -0.05 & 0.42 \\
\hline $\begin{array}{l}\text { Remanded and/or convicted } \\
\text { and in treatment }\end{array}$ & 1 & $0.56^{* *}$ & 0.42 & 0.70 \\
\hline Type of crime & & & & \\
\hline Capital crimes & No. of studies & Hedge's g & $\mathbf{9 5 \%}$ CI LL & $\mathbf{9 5 \%}$ CI UL \\
\hline $\begin{array}{l}\text { Mixed crimes (felonies, } \\
\text { misdemeanours, violations) }\end{array}$ & 1 & $0.76^{* *}$ & 0.34 & 1.18 \\
\hline Partner violence & 1 & $0.56^{* *}$ & 0.42 & 0.70 \\
\hline Source of reference scores & 2 & -0.19 & -0.95 & 0.57 \\
\hline General norms & 7 & Hedge's g & $\mathbf{9 5 \%}$ CI LL & $\mathbf{9 5 \% ~ C I ~ U L ~}$ \\
\hline Original article & 1 & -0.27 & -0.84 & 0.31 \\
\hline Note. CI Confies & $0.79^{* *}$ & 0.34 & 1.24 \\
\hline
\end{tabular}

Note. $\mathrm{CI}=$ Confidence interval. $\mathrm{LL}=$ Lower limit. $\mathrm{UL}=$ Upper limit.

$*=p<.05 . * *=p<.01$ 